\title{
On the presence of DNA polymerase $\alpha$ in human Iymphocyte nuclei and chromosomes
}

\author{
M. G. ENNAS, H. SUZUKI†, M. MENEGAZZI†, A. CARCERERI†, F. HANAOKA $\ddagger$ \\ F. GREMO, M. NIEDDU§ \& R. MEZZANOTTEß* \\ Dipartimento di Citomorfologia, Università di Cagliari, Italy, †/stituto di Chimica Biologica, Università di Verona, Italy, \\ $\ddagger / n s t i t u t e$ of Physical and Chemical Research (Riken), Wako, Saitama, Japan and \$lstituto di Biologia Generale, \\ Università di Cagliari, Italy
}

\begin{abstract}
Experiments were carried out to correlate the cytological localization of DNA polymerase $\alpha$ with the presence of its specific mRNA in human lymphocytes studied at different times after phytohaemagglutinin stimulation. Our data indicated that in resting cells it is not possible to detect DNA polymerase $\alpha$ protein or mRNA by Northern hybridization. By contrast, in stimulated cells the detection of mRNA specific for DNA polymerase $\alpha$ synthesis is possible after $16 \mathrm{~h}$ phytohaemagglutin stimulation, whereas immunolocalization is possible after only 4 h stimulation. Observation of cytological preparations from cells stimulated for times long enough to obtain mitoses surprisingly showed an intense immunoreaction in mitotic chromosomes treated with monoclonal antibodies to DNA polymerase $\alpha$.
\end{abstract}

Keywords: cell cycle, chromatin, chromosomes, DNA polymerase $\alpha$, DNA synthesis, .

\section{Introduction}

DNA replication always precedes cell division and, as such, is one of the most important, complicated reactions in living organisms. In eucaryotic cells, the perfect completion of this reaction is guaranteed by a number of coordinately functioning enzymes such as topoisomerases and various types of polymerases (Linn, 1991). Two structurally distinct types of DNA polymerases are known: (i) the alpha-type which includes polymerases $\alpha, \delta$ and $\varepsilon$, which are possibly involved in DNA synthesis of both leading and lagging strands; and (ii) the $\beta$-type which includes the polymerases mostly involved in DNA repair mechanisms (Chiu \& Baril, 1975), although their possible role in DNA synthesis has only recently been suggested (Suzuki et al., 1991). Among the above cited enzymes, DNA polymerase $\alpha$ has been studied in detail and appears to play a critical role in DNA synthesis because of its enhanced activity in

*Correspondence. Istituto di Biologia Generale, Facoltà di Medicina, Università, Via Ospedale 119, 09124 Cagliari, Italy. proliferating cells (Bambara \& Jessee, 1991), as well as its association with primase activity (Nethanel \& Kaufmann, 1990; Bullock et al., 1991). DNA polymerase $\alpha$ exists in mammals as a complex with DNA primase and is composed of four subunits with a molecular mass of $180,68-77,55$ and $48 \mathrm{kDa}$ (Kozu et al., 1990). The intracellular localization of this enzyme is still controversial. In fact, although some reports suggest its presence in the cytoplasm (Bollum, 1975; Brown et al., 1981), other data indicate the nuclear localization of DNA polymerase $\alpha$ (Masaki et al., 1982; Tanaka et al., 1982; Matsukage et al., 1983). In particular, it has been found in association with the nuclear matrix which, as a consequence, is believed to play some fundamental role in DNA synthesis (Foster \& Collins, 1985; Smith \& Berezney, 1983; Collins \& Chu, 1987). In turn, as the nuclear matrix is duplicated during the $S$ phase and segregated during cell division (Cook, 1991), the localization of DNA polymerase in mitosis becomes of critical importance.

On these bases, and taking into account that the data available to date exclude the presence of DNA 
polymerase $\alpha$ in mitotic chromosomes (Nakamura et al., 1984; Stokke et al., 1991), we further investigated the localization of this enzyme. The study was carried out on human peripheral blood mononuclear cells, both resting and after phytohaemagglutinin stimulation, during different consecutive cell cycles.

\section{Materials and methods}

\section{Cell isolation and culture}

Human mononuclear cells were isolated from the peripheral blood of healthy donors by centrifugation on Ficoll-Hypaque density gradients. Cells were cultured in macrowells at $2 \times 10^{6} / \mathrm{mL}$ in RPMI 1640 containing 10 per cent $(\mathrm{v} / \mathrm{v})$ foetal calf serum in the presence of phytohaemagglutinin (PHA, Gibco, 1 per cent $\mathrm{v} / \mathrm{v}$ ). The cells cultured in the presence of PHA were grown for 4, 8, 16, 24, 48, 96 and $120 \mathrm{~h}$ before harvesting and initiating the experimental procedures below.

\section{Monoclonal antibody analysis}

To preserve the native structure of cell components, these experiments were carried out by placing unfixed nuclei and chromosomes, obtained from PHA-stimulated lymphocytes, on clean slides by centrifugation for $4 \mathrm{~min}$ at $75 \mathrm{~g}$ with a Shandon II cytospin. Cells were fixed in 4 per cent paraformaldehyde, $0.1 \mathrm{M}$ Saccarose for $5 \mathrm{~min}$ at room temperature. In some cases, mitotic preparations were obtained by treating PHA-stimulated lymphocytes with hypotonic solution $(0.07 \mathrm{M} \mathrm{KCl})$ for $15 \mathrm{~min}$ at $37^{\circ} \mathrm{C}$. Several washes in phosphate buffer ( $\left.\mathrm{pH} 7.4\right)$ and one in phosphate-buffered saline (PBS), 0.2 per cent Triton X-100 were effected prior to immunostaining. Slides were then incubated with $20-40 \mu \mathrm{g}$ $\mathrm{mL}^{-1}$ monoclonal antibody (McAb) to DNA polymerase $\alpha$ (either SJK 287 or E4; see Tanaka et al., 1982; Kozu et al., 1990; Takada-Takayama et al., 1990 ) for $1 \mathrm{~h}$ at room temperature. After several washes in PBS-Triton X-100, preparations were incubated with biotinylated IgG antimouse (Vector, USA, 1:200 for $30 \mathrm{~min}$ at room temperature) and then with biotinylated acetyl-avidin complex (Bio Division, Italy; $1: 250$ for $30 \mathrm{~min}$ at room temperature). Immunostaining was carried out using $3^{\prime}-3^{\prime}$-diaminobenzidine tetrachloride (Sigma; $3 \mathrm{mg}$ $\mathrm{mL}^{-1}$ ) and 0.3 per cent hydrogen peroxide in PBS. The immunoreaction negative controls were effected using horse serum (1:100) instead of McAb to DNA polymerase $\alpha$.
In some cases, Giemsa staining (5 per cent in deionized water) was used to make control chromosomes and nuclei evident.

\section{Northern hybridization analysis}

Total cellular RNA was extracted from $1 \times 10^{8}$ peripheral blood lymphocytes with guanidium isothiocyanate, and purified by centrifugation using $5.7 \mathrm{M}$ $\mathrm{CsCl}$ (Chirgwin et al., 1979). The RNA (30 $\mu \mathrm{g}$ per track) was then electrophoresed on a 0.8 per cent denaturing agarose gel and transferred to a Hybond $\mathrm{N}$ membrane (Amersham). The UV-irradiated filter was hybridized with ${ }^{32} \mathrm{P}$-labelled cDNA for human DNA polymerase $\alpha$ and for histone H3. Before and after RNA transfer to the nylon membrane, the gel was stained with ethidium bromide to evaluate the amount of transferred RNA.

\section{Results}

\section{$M c A b$ analysis}

Identical results were found when experiments were carried out using either SJK 287 or E4 McAb. For brevity we will describe and discuss only those results obtained with McAb SJK 287. A negative immunoreaction was observed in: (i) control preparations; (ii) nonstimulated, resting lymphocytes prepared just after PHA stimulation; and (iii) nuclei observed after $0-3$ h PHA stimulation. On the contrary, intense brown staining was found in preparations of lymphocytes after $4 \mathrm{~h}$ PHA stimulation (Fig. 1), although stain intensity and the number of labelled cells increased with an increase in time after stimulation (Fig. 2). In detail, some nuclei (about 5-10 per cent) showed moderate immunolabelling that appeared granular in preparations studied after $4 \mathrm{~h}$ from PHA stimulation. In preparations studied after 8,16 and $24 \mathrm{~h}$ from PHA stimulation, immunostain intensity was more homogeneous and the number of labelled nuclei higher (about 20, 30 and 50 per cent, respectively) compared with what we observed in preparations of $4 \mathrm{~h}$ stimulated cells. Immunoreaction was maximum in both stain intensity and the number of labelled nuclei (about 90 per cent) in preparations studied after 48, 72 and $96 \mathrm{~h}$ from PHA stimulation. Chromosomes revealed intense immunostaining during each step of mitosis, whereas the cytoplasm of all cells showed scarce reaction.

An intense immunoreaction with $\mathrm{McAb}$ to DNA polymerase $\alpha$ was found in human mitotic chromosomes obtained not only from lymphocytes but also

(C) The Genetical Society of Great Britain, Heredity, 77, 186-191. 

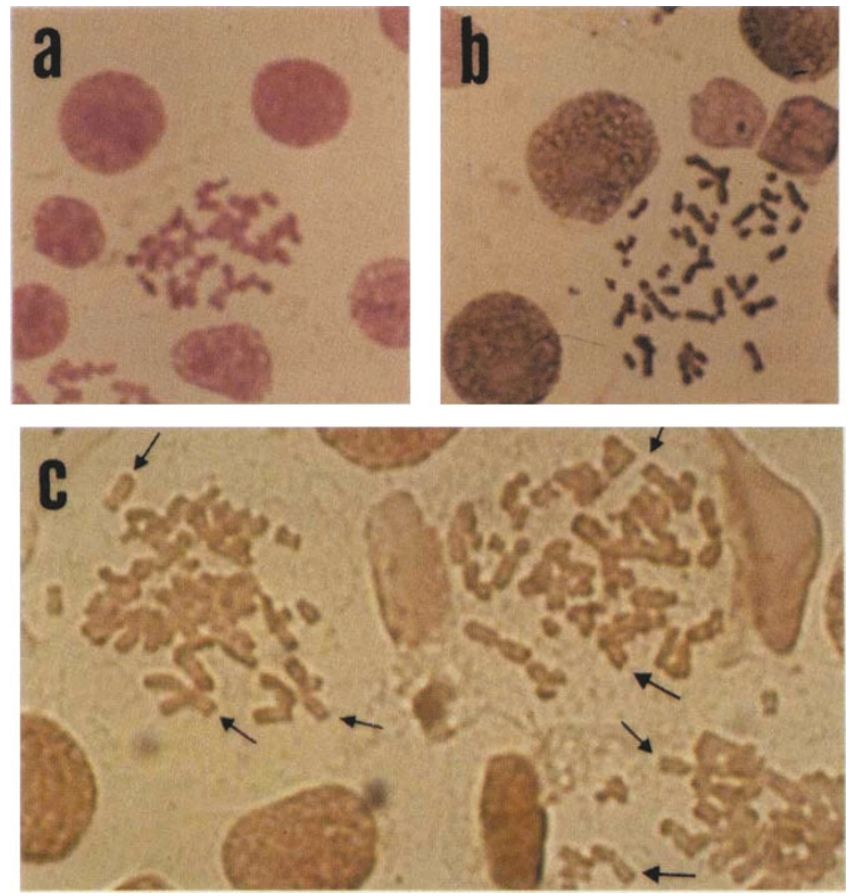

Fig. 1 (a) Human mitotic chromosomes from peripheral blood lymphocytes stimulated with PHA were prepared by cytospin, treated with horse serum (negative control) and counterstained with Giemsa. Note that chromosomes show Giemsa staining and no peroxidase reaction. (b) A very intense peroxidase reaction is present in cytospinned chromosomes that appear brown in colour after immunoreaction with McAb SJK 287 and subsequent Giemsa staining. (c) Human chromosomes treated with $\mathrm{McAb}$ SJK 287 but not counterstained with Giemsa. Note that intense immunostaining is present in some telomeric regions (see arrows).

from hepatoma cell line, as well as from foetal brain cells (M. G. Ennas, unpublished data).

\section{Northern hybridization analysis}

No hybridization occurred between cDNA and DNA polymerase $\alpha$ using the RNA isolated immediately after (time 0 ) or $4 \mathrm{~h}$ after PHA stimulation. A faint signal, difficult to detect, was found when hybridization was carried out using RNA samples isolated from lymphocytes stimulated with PHA for 8-16 h. A moderate, although clearcut signal was present in hybridization experiments carried out using RNA samples obtained from cells stimulated for 24-48 h, and became very intense when RNA samples were obtained from 72-96 h stimulated cells. Conversely, hybridization with cDNA to histone $\mathrm{H} 3$ and $\beta$ actin showed labelling in correspondence with RNA isolated after 48, 72, 96 and $120 \mathrm{~h}$ PHA stimulation (Fig. 3).

\section{Discussion}

Very few data are available on the localization of DNA polymerase $\alpha$ on mitotic chromosomes with McAbs and, among such data, only those obtained by Nakamura et al. (1984) specifically describe results obtained on human lymphocyte mitotic chromosomes. In all cases, it seems that the abovecited immunoreaction occurs in the cytoplasm but not on chromatin (Nakamura et al., 1984; Stokke et al., 1991). Our data, on the contrary, show intense immunoreaction in human nuclei and mitotic chromosomes after McAb staining. This apparent contradiction might be explained by the fact that the above-cited authors employed procedures that were different compared with those used in our experiments. For instance, a different McAb was employed by Nakamura et al. (1984), whereas Stokke et al. (1991), although using the same SJK 287-38 McAb, employed peripheral blood human B lymphocytes stimulated with anti- $\mu$ and low molecular weight B cell growth factor (PHA was the stimulating agent, known for acting on T lymphocytes; see Mandel et al., 1977, in our experiments). Moreover, our results were obtained on cytological material treated with the $\mathrm{McAb}$ immediately after preparation, as storage of slides at $-20^{\circ} \mathrm{C}$ resulted in poor, faint immunostaining (M. G. Ennas, unpublished data). On the other hand, other data exist that do not dramatically contrast with our data. Bensch et al. (1982), using the SJK 287-38 McAb on two transformed cell lines maintain that the 'localization of DNA polymerase $\alpha$ is essentially intranuclear', although reporting that in mitotic cells, whose nuclear envelope is not present, 'the polymerase antigen appears to be freely distributed throughout the cytoplasm compartment'. Furthermore, Martelli et al. (1990) showed an association of DNA polymerase $\alpha$ activity with the nuclear matrix, and very recently Brenot-Bosc et al. (1995) have shown that DNA polymerase $\alpha$ has a predominantly nuclear location in the $G_{1}$ phase of actively growing Manca cells. Metabolic activity is practically nil during mitosis, so the last fact strongly agrees with DNA polymerase $\alpha$ localization on mitotic chromosomes. In this connection, we stress our finding of positive immunolabelling not only on human lymphocyte but also on human hepatoma metaphase chromosomes.

If DNA polymerase $\alpha$ is actually part of mitotic chromosome structure, the coincident pattern of intense labelling found when comparing DNA poly- 

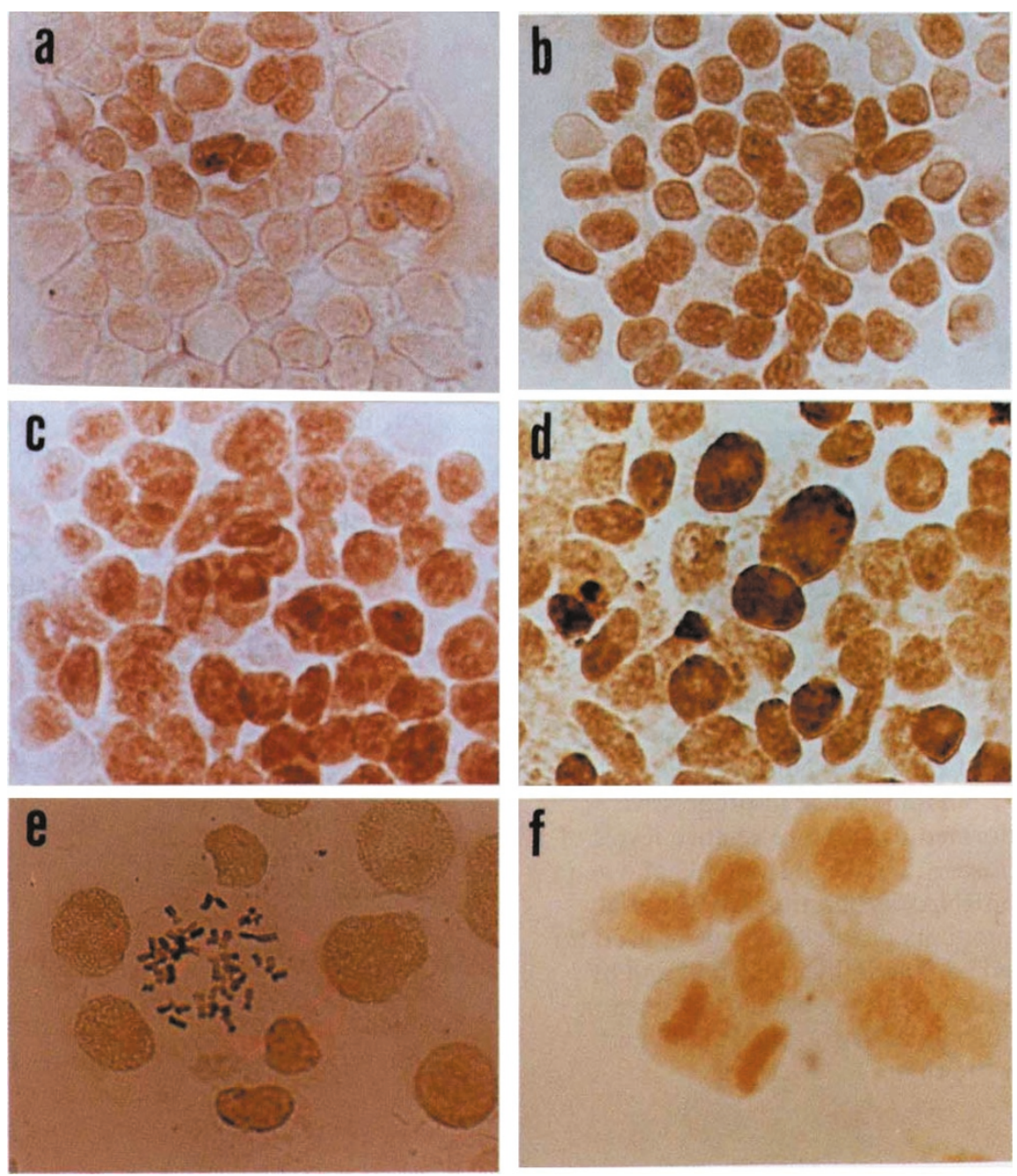

Fig. 2 Human lymphocytes prepared by cytospin and stained with McAb to DNA polymerase $\alpha$ after PHA stimulation for $4,8,16-24 \mathrm{~h}$ and $48-72-96 \mathrm{~h}$ are shown respectively in (a), (b), (c) and (d). Note the progressive increase in stain intensity and number of nuclei labelled, from a moderate reaction (a), a granular-like reaction (b), to an intense reaction (c, d). Also note that in (c) and (d) not all the nuclei are labelled, possibly because between B and T lymphocytes, PHA stimulates only some cells of the T population, and among $\mathrm{T}$ lymphocytes not all are stimulated at the same time (Mandel, 1977). Lymphocyte mitotic chromosomes, prepared by cytospin centrifugation, show intense immunoreaction both in metaphase (e) and anaphase (f).

merase $\alpha$ and histone $\mathrm{H} 3$ (indicative of DNA synthesis) Northern blot hybridization is not surprising. Therefore, DNA polymerase $\alpha$, synthesized during S phase like all nuclear proteic components (Zetterberg, 1966), might act not only to catalyse DNA replication but also to double chromosome components that must be distributed to daughter cells during subsequent mitotic division.

The correlation between our cytological and biochemical data shows that mRNA specific for DNA polymerase $\alpha$ is not present, or is present at a level difficult to detect, when the enzyme is already present, as monitored by immunoreaction in nuclei (4, 8 and $16 \mathrm{~h}$ after PHA stimulation), thus supporting the hypothesis of the possible structural role played by DNA polymerase $\alpha$ in chromatin structure. In this connection, Smith \& Berenzney (1983) state that 'DNA polymerase $\alpha$ is dynamically assembled or activated on the nuclear matrix and that this process is initiated before the onset of in vivo replication', whereas it is known that other enzymes involved in DNA synthesis such as Topoi- 


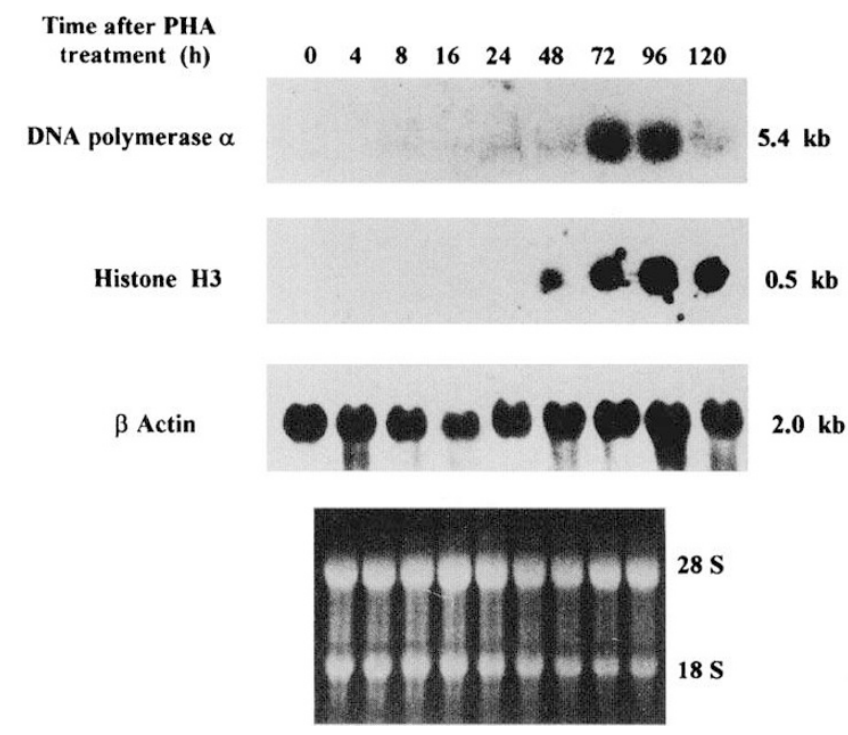

Fig. 3 Steady-state mRNA levels of human DNA polymerase $\alpha$ in peripheral blood human lymphocytes, cultured in the presence of PHA for different times (h), as indicated at the top of the panel. Northern blot hybridization of total RNA from quiescence to progressive proliferation was performed to measure relative levels of human DNA polymerase $\alpha(5.4 \mathrm{~kb})$, histone $\mathrm{H} 3$ and actin $(2.0 \mathrm{~kb})$ steady-state mRNAs as described in Materials and methods. Equal amounts of total RNA were used for each point and verified by $\beta$ actin hybridization and by ethidium bromide staining of rRNA bands, as shown in the lower part of the panel; rRNA positions (28S and $18 \mathrm{~S}$ ) are indicated on the right.

somerase II and DNA polymerase $\beta$ are part of chromosome structure (Earnshaw et al., 1985; Menegazzi et al., 1991).

\section{References}

Bambara, R. A. AND Jessee, C. B. 1991. Properties of DNA polymerases and their role in eukaryotic DNA replication. Biochem. Biophys. Acta, 1088, 11-24.

BENSCH, K. G., TANAKA, S., HU, S. Z., WANG, T. S. F. AND KORN, D. 1982. Intracellular localization of human DNA polymerase with monoclonal antibodies. J. Biol. Chem., 257, 8391-8396.

Bollum, F. J. 1975. Mammalian DNA polymerases. Prog. Nucleic Acids Res. Mol. Biol., 15, 109-144.

BRENOT-BOSC, F., GUPTA, S., MARGOLIS, R. L. AND FOTEDAR, R. 1995. Changes in the subcellular localization of replication initiation proteins and cell cycle proteins during $\mathrm{G}_{1}$ - to S-phase transition in mammalian cells. Chromosoma, 103, 517-527.

BROWN, M., BOLLUM, F. J. AND CHANG, L. M. s. 1981. Intracellular localization of DNA polymerase $\alpha$. Proc. Natl.
Acad. Sci. U.S.A., 78, 3049-3052.

BULLOCK, P. A., SEO, Y. S. AND HURWITZ, J. 1991. Initiation of simian virus 40 DNA synthesis in vitro. Mol. Cell. Biol., 11, 2350-2361.

CHIRGWIN, J. M., PRZYBYLA, A. E., McDONALD, R. J. AND RUTTER, w. J. 1979. Isolation of biologically active ribonucleic acid from sources enriched in ribonuclease. Biochemistry, 18, 5294-5299.

CHIU, R. W. AND BARIL, E. F. 1975. Nuclear DNA polymerases and the HeLa cell cycle. J. Biol. Chem., 250, 7951-7957.

COLLins, J. M. AND CHU, A. K. 1987. Binding of the DNA polymerase $\alpha$-DNA primase complex to the nuclear matrix in HeLa cells. Biochemistry, 26, 5600-5607.

СоOK, P. R. 1991. The nucleoskeleton and the topology of replication. Cell, 66, 627-635.

EARNSHAw, w. C., HALLIGAN, B., COOKE, C. A., HECK, M. M. S. AND LIN, L. F. 1985 . Topoisomerase II is a structural component of mitotic chromosome scaffolds. J. Cell Biol., 100, 1706-1715.

FOSTER, K. A. AND COLLINS, J. M. 1985. The interrelation between DNA synthesis rates and DNA polymerases bound to the nuclear matrix in synchronized HeLa cells. J. Biol. Chem., 260, 4229-4235.

KOZU, T., NIKAIDO, K. AND YAGURA, T. 1990. Structure of DNA polymerase $\alpha$-primase complexes from mammalian cells by using monoclonal antibodies. J. Biochem., 107, 535-538.

LINN, s. 1991. How many pols does it take to replicate nuclear DNA? Cell, 66, 185-187.

MANDEL, T. E. 1977. The ultrastructure of mammalian lymphocytes and their progeny. In: Marchaloniss, J. J. (ed.) The Lymphocyte. Structure and Function. Part I, p. 27. Marcel Dekker, New York and Basel.

MARTELLI, A. M., GlLMOUR, R. S., FALCIERI, E., MANZOLI, F. A. AND COCCO, L. 1990. Temperature-dependent association of DNA $\alpha$ polymerase activity with the nuclear matrix. Exp. Cell Res., 190, 227-232.

MASAK1, S., SHIKU, H., KANEDA, T., KOIWAI, O. AND YOSHIDA, s. 1982. Production and characterization of monoclonal antibody against $10 \mathrm{~S}$ DNA polymerase $\alpha$ from calf thymus. Nucl. Acids Res., 10, 4703-4713.

matsukage, A., Yamamoto, s., Yamaguchl, M., KusaKABE, M. AND TAKAHASHI, T. 1983. Immunocytochemical localization of chick DNA polymerase $\alpha$ and $\beta$. Cell. Physiol., 117, 266-271.

MENEGAZZI, M., GRASSI-ZUCCONI, G., CARCERERI DE PRATI, A., OGURA, T., POLTRONIERI, P., NYUNOYA, H., SHIRATORI-NYUNOYA, Y., MIWA, M. AND SUZUKI, H. 1991. Differential expression of poly (ADP- ribose) polymerase and DNA polymerase $\beta$ in rat tissues. Exp. Cell Res., 197, 66-74.

NAKAMURA, H., MORITA, T., MASAKl, s. AND YOSHIDA, s. 1984. Intracellular localization and metabolism of DNA polymerase $\alpha$ in human cells visualized with monoclonal antibody. Exp. Cell Res., 151, 123-133.

NETHANEL, T. AND KAUFMANN, G. 1990. Two DNA polymerases may be required for synthesis of the lagging DNA strand of simian virus 40. J. Virol., 64, 5912-5918. 
SMITH, H.C. AND BEREZNEY, R. 1983. Dynamic domains of DNA polymerase $\alpha$ in regenerating rat liver. Biochemistry, 32, 3042-3046.

STOKKE, T., ERIKSTEIN, B., HOLTE, H., FUNDERUD, S. AND STEEN, H. B. 1991. Cell-cycle specific expression and nuclear binding of DNA polymerase $\alpha$. Mol. Cell. Biol., 11, 3384-3389.

SUZUKI, H., MENEGAZZI, M., CARCERERI DE PRATI, A., OGURA, T., ESUMI, H., MATSUKAGE, A. AND LIBONATI, M. 1991. Induction of DNA polymerase $\beta$ during proliferation of mitogen-stimulated human lymphocytes. Biochem. Biophys. Res. Commun., 181, 623-626.
TAKADA-TAKAYAMA, R., TADA, S., HANAOKA, F. AND UI, M. 1990. Peptide mapping of the mouse DNA polymerase $\alpha$-primase complex. Biochem. Biophys. Res. Commun., 170, 589-595.

TANAKA, s., HU, s., WANG, S. F. AND KORN, D. 1982. Preparation and preliminary characterization of monoclonal antibodies against human DNA polymerase $\alpha . J$. Biol. Chem., 257, 8386-8390.

ZETTERBERG, A. 1966. Synthesis and accumulation of nuclear and cytoplasmic proteins during interphase in mouse fibroblasts in vitro. Exp. Cell Res., 42, 500-511. 